\title{
日射量を用いた CIE 標準一般天空の天空タイプ推定手法に関する研究 STUDY ON IDENTIFYING THE SKY TYPES RECOMMENDED AS CIE STANDARD GENERAL SKY BY MEASURED FLUX OF SOLAR RADIATION
}

\author{
細 淵勇人*1, 吉田治典*2, 上谷芳昭*3 \\ Hayato HOSOBUCHI, Harunori YOSHIDA and Yoshiaki UETANI
}

\begin{abstract}
In this paper, by using the sky luminance distribution model of the CIE standard general sky in place of the measured sky radiance distribution, the authors propose the method of identifing the sky types of the CIE standard general sky using values of horizontal global sky radiation (Eeg), normal direct solar radiation (Ees), without measuring the sky radiance distribution which is measured rarely.

1) The sky type of CIE standard general sky is determined by the set of parametrised Gradation and Indicatrix functions. So, to identify the set of parameter values of Gradation function and that of Indicatrix function, the regression curves are fitted to the correlation between the sun's height and Eeg in Gradation functions and the correlation between Ees and Eed in Indicatrix functions respectively in each sky types.

2) Using the relation between the fitted regression curves and the sun's height and i) Eeg in Gradation function, and ii) Ees in Indicatrix function, the set of parameter values of Gradation function and that of Indicatrix function are identified.

By the each set of parameter values of two functions, the sky type is identified. And, using the sky radiance distribution of the identified sky type, the vertical irradiance values are calculated.
\end{abstract}

Keywords : Sky Radiance Distribution, CIE Standard General Sky, Sky Type, Vertical Irradiance 天空放射輝度分布，CIE 標準…般天空，天空タイプ，鈶直面日射量

\section{1. 序}

昼光・日射分野の気象モデルの研究では, 天空輝度分布, 天空放 射輝度分布を, 晴れから曇りに至る天空状態の違いを考慮し，いく つかの天空タイプに分類してモデル化するのが一般的である1223). これらのモデルのうち, 輝度階調関数 (Gradation function) と散乱 関数（Indicatrix function）という二つの関数によって, 啨天空から 曇天空を 15 の天空タイプで表すKittler, Perezら ${ }^{4)}$ の相対天空輝度 分布のモデルは国際照明委員会 (Commission Internationale De L'eclairage(CIE)) により標準一般天空 ${ }^{5)}$ として採用されている.

筆者らは,熱環境予測において現在一般的に一様であると仮定さ れる天空放射輝度分布に, この標準一般天空モデルを流用し, 次の ことを示した ${ }^{6}$. 1) 15 の天空タイプと測定値との差の RMSE (Root Mean Square Error)によって，測定された天空放射輝度分布に一番 近い天空タイプ (近似タイプ) を決定すれば, これより害際の天空 放射輝度分布から得られる方位別鉛直面日射量により近い精密な方 位別鉛直面日射量が求められる. 2) 15 の天空タイプを出現頻度の 高い5つの天空タイブに集約して方位別鉛直面日射量を求めても， 測定された天空放射輝度分布より求めた方位別鉛直面日射量に対す る相対誤差に大きな差はない.

天空タイプの推定には天空放射輝度分布の測定值が必要であるが,
天空放射輝度分布は通常測定されていないため, 他の地域の分布を 推定するには, 通常よく測定されている気象要素を用いて, 天空夕 イプを推定する手法の開発が必要である. そこで本報では, 1)水平 面全天日射量や, 法線面直達日射量といった気象要素と, 天空放射 輝度分布の測定値に最も近い天空タイプ(近似タイプ)の関係を見 出して, その関係より天空タイプを推定する手法を開発し，2）推 定した天空タイプを用いて東西南北四方位の鈶直面日射量を求め, 天空放射輝度分布測定值から得られた方位別鈆直面日射量に対する 相対誤差を分析し, その精度より本手法の妥当性を検証する.

\section{2. 日射量・天空放射輝度分布の測定值}

本研究では, C I E の国際昼光測定プログラム ( C I E IDMP(International Daylight Measurement Programme) に準拠して, 京都大学で測定を行っている気象データのうち, 2001年1月1日か ら 2001 年 12 月 31 日までの 1 年間の天空放射輝度分布, 天空輝度分 布, 水平面全天日射量, 法線面直達日射量データを用いて分析 を行う. 表 1 に测定項目及び測定機器, 表 2 に測定地点の概要を示 す. 分析に先立ち, 毎日 4:00から 19:00まで 6 月以降は $20: 00$ まで)の時間帯において15分間隔で自動測定した天空放射輝度と天 空輝度分布の測定值, 及び全天日射計および直達日射計の1分間隔
*1 京都大学大学院工学研究科環境地球工学専攻

博士課程 · 工修

*2 京都大学大学院工学研究科都市䍗境工学専攻 教授 - 工博

*3 京都大学大学院工学研究科都市環境工学専攻 助教授. 工博
Graduate Student, Dept. of Global Environmental Eng., Grad. of Eng., Kyoto University, M. Eng.

Prof., Dept. of Urban and Environmental Eng., Grad. of Eng., Kyoto University, Dr. Eng.

Assoc. Prof., Dept. of Urban and Environmental Eng., Grad. of Eng., Kyoto University, Dr. Eng. 
測定值に対して，補正注1) 及びCIEガイドによるデータの品質管理 テスト718) を適用し, 上記の測定值のうちの一つでも不合格となった 時間の測定值は分析対象から除外する. また太陽高度が $5^{\circ}$ 以下の時 刻の測定值については周辺事物の影響を受けていると考え,これも 除外する。

\section{3. 天空タイプと日射量}

\section{1 Gradation,Indicatrix グループと日射量}

Kittler，Perezらによれば，CIE標準一般天空を構成する輝度階調 関数 (Gradation function, 式 (1)，(2) ) とは天頂を中心とする円状の 輝度分布を, 散乱関数 (Indicatrix function, 式 (3)，(4)) とは太陽 (位 置）を中心とする円状の輝度分布を表す関数のことをいう5) . 天空 タイブと日射量との関係の分析には,それぞれの分布を表現する輝 度階調, 散乱関数の各グループと気象要素との関係を分析する方が, その関係をより明確に見出せると考える. 本報は, 通常よく測定さ れている気象要素から天空タイプを容易に推定する手法の開発を目 的とするため, 天空要素の高度に依存する輝度階調関数 (Gradation function)では,より一般的に測定されている気象要素である水平面 全天日射量Eegを, 太陽高度, 太陽方位といった太陽位置の関数で ある散乱関数（Indicatrix function）では，太陽位置に関係する法線 面直達日射量Eesをそれぞれ分析対象とする。

$$
\begin{aligned}
& \varphi(Z)=1+a \cdot \exp \left(\frac{b}{\cos Z}\right) \\
& \varphi\left(\frac{\pi}{2}\right)=1 \\
& f(\chi)=1+c \cdot\left[\exp (d \chi)-\exp \left(d \frac{\pi}{2}\right)\right]+e \cdot \cos ^{2} \chi \\
& f\left(Z_{s}\right)=1+c \cdot\left[\exp \left(d Z_{s}\right)-\exp \left(d \frac{\pi}{2}\right)\right]+e \cdot \cos ^{2} Z_{s} \\
& \chi=\arccos \left(\cos Z_{s} \cdot \cos Z+\sin Z_{s} \cdot \sin Z \cdot \cos \left|\alpha-\alpha_{s}\right|\right) \\
& \text { ここで, } \\
& \chi \quad \text { : 太陽と天球上任意点の角距離 [ } \mathrm{rad}] \\
& Z \text { : 天球上任意点の天頂角 }[\mathrm{rad}] \\
& Z_{s} \quad \text { : 天頂からの太陽高度 [rad] } \\
& a, b \quad \text { : 輝度階調関数のバラメータ [-] } \\
& c, d, e \text { : 散乱関数のバラメータ [-] } \\
& \alpha \text { : 天球上任意点の方位角 }[\mathrm{rad}] \\
& \alpha_{s} \quad \text { : 太陽方位角 [rad] }
\end{aligned}
$$

図 1a)に，测定された天空放射輝度分布と 15 の天空タイブとの

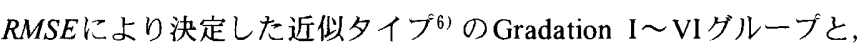
同時刻の水平面全天日射量 $E e g\left[\mathrm{~W} / \mathrm{m}^{2}\right]$ (スカイスキャナ測定開始時

\begin{tabular}{|c|c|c|c|c|}
\hline S廷地点 & & 童在 & & 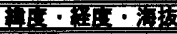 \\
\hline $\begin{array}{c}\text { 京都大学 } \\
\text { 工学部 7号刢屋上 }\end{array}$ & 京都市 & 左京区 & 吉田本町 & $\begin{array}{c}\text { 北緯 } 35^{\circ} 1^{\prime} \\
\text { 東経 } 135^{\circ} 47^{\prime} \\
\text { 海抜 } 90 \mathrm{~m} \\
\end{array}$ \\
\hline
\end{tabular}
刻の瞬時值）との関係を, 図 1b)にはIndicatrix 1〜6グルーブと法 線面直達日射量 $E e s\left[\mathrm{~W} / \mathrm{m}^{2}\right]$ （Eeg と同様）の関倸を示す

図 1a) から, Gradationには,グルーブの番号が大きくなるほど水 平面全天日射量 Eegが大きくなり, かつEegの分散が減るという傾 向が見られる.グループ I, II, グループIII, IV，グループV，VIそ れぞれのEegのとる範囲は，グルーブで明確に分離されない。また 図1b) から Indicatrix ，Gradationと同様にグループの番号が大きく なるほどEesは大きくなる傾向があるが, グループ4では, 観測され るEesの分散が特に大きい.
表 1 測定項目及び測定機器

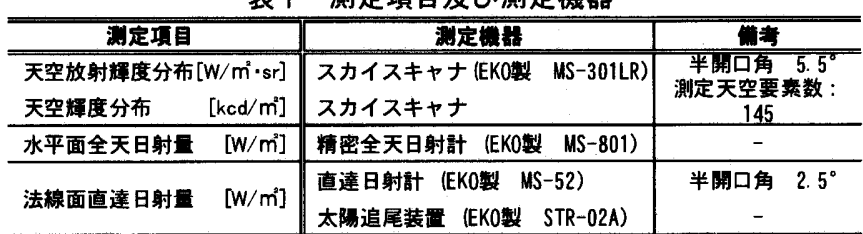

表 2 測定地点の概要
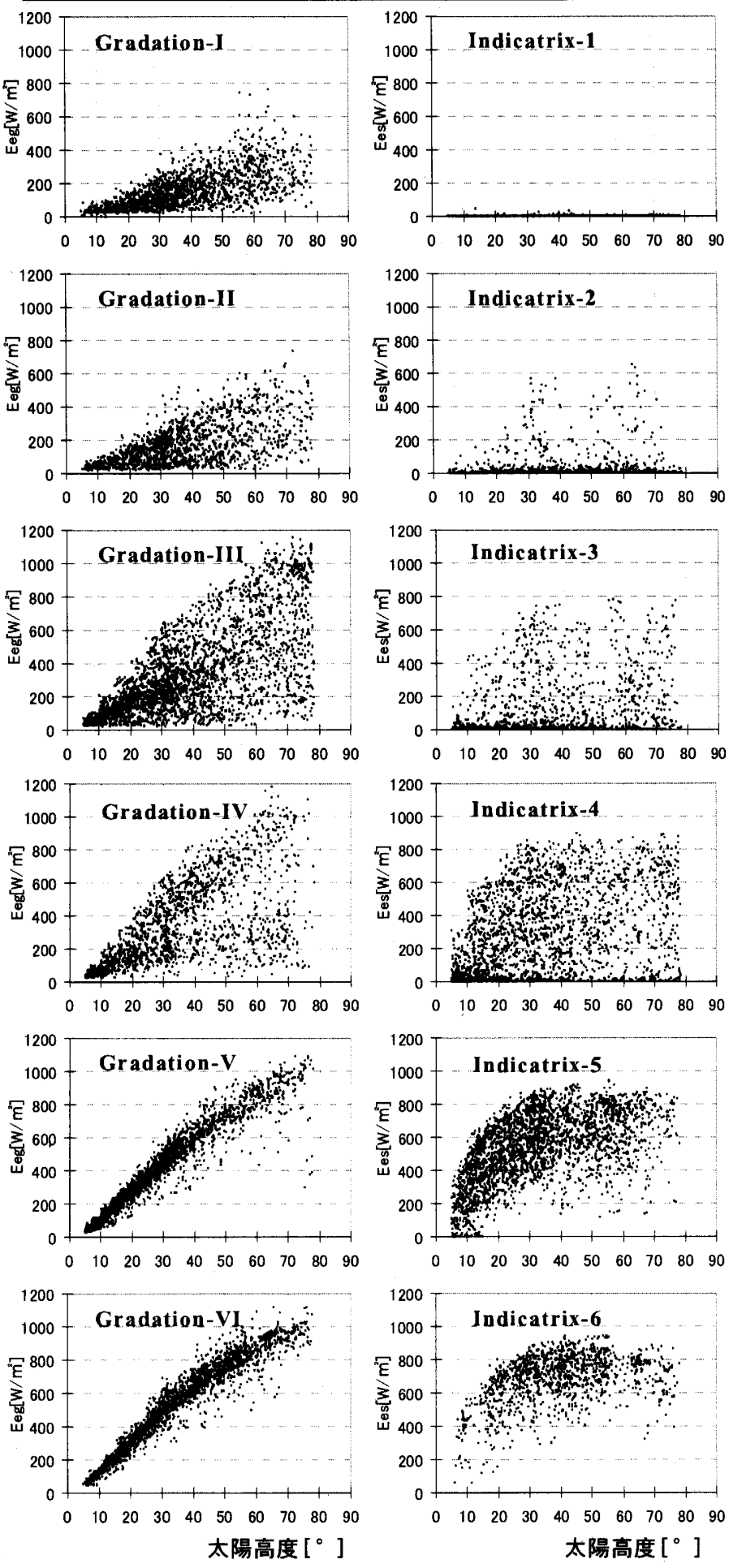

a) Gradation

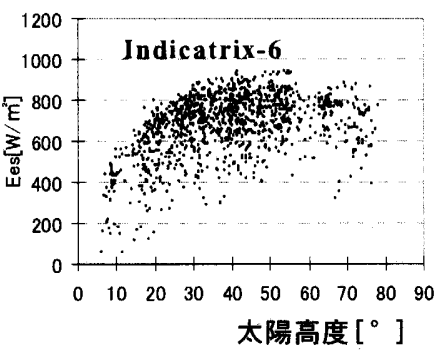

b) Indicatrix

図 1 Gradation, Indicatrix と日射量測定值の開任 
以上のように, Gradation, Indicatrixともにグループの番号が大き くなるほど日射量は大きくなるが, その分散が大きかったり, 日射 量の範囲が, 他のグループの日射量の範囲と明確に分離されないグ ループが見られるため, 図1のような散布図では近似タイプと日射 量の関係を明らかにすることは困難である，そこで日射量と Gradation, Indicatrixの各グループの関係をより明確に把握するため に, Gradation, Indicatrixの各グループに対応する日射量の平均値を 太陽高度幅 $5^{\circ}$ ごとに求め, その平均値とGradation, Indicatrixの各 グループの関倸を分析する. 図2に示すように, Gradation, Indicatrix ともに同じ高度に対し,グループの番号が大きくなるほど日射量の 平均値は大きくなる.

\section{2 日射量の分析}

天空放射輝度分布は毎正時から 15 分間隔で, 水平面全天日射量 Eeg, 法線面直達日射量Eesは同じく1分間隔で測定を行っている. スカイスキャナによる天空放射輝度分布の測定にはおよそ2分 40 秒 を要するので，この閒に日射量の測定は 3 回行われる. 天空タイプ をより精度良く決定する日射量を選定するためには，この3回の測 定で得られる日射量測定值のうちから,その時刻の近似タイプと相 関が最も高いものがどれであるかを把握する必要がある。また, 水 平面全天日射量Eeg, 法線面直達日射量Eesは, 例えば太陽を覆うよ うな雲が存在するとその值は短時間のうちに変化することもあるが, 天空放射輝度分布を考えた場合, 局所的な雲の出現等が, 分布全体 にもたらす変化は大きくないことも考えられる.このため天空放射 輝度分布と日射量との関係を分析する際には, ある時刻の天空放射 輝度分布を表す天空タイプと日射量との瞬間的な関係だけではなく, その時刻の前後で測定された日射量の影響も考慮して関係を分析す る必要がある.

そこで，図 3 に示すように，スカイスキャナ測定開始後 $0 ， 60$, $120 \mathrm{sec}$ を心として，それぞれ前後 $420 \mathrm{sec}$ の範囲で $0 ， 180 ， 300$, $420 ， 540 ， 660 ， 780,900 \mathrm{sec}$ と平均化時間を変えて, Eeg, Ees の 平均值を Gradation, Indicatrix 各グルーブごとに算出し, Eeg, Ees 測定值に代えて分析用データEeg', Ees'とする (つまり, 各平均化 時間ごとにEeg, Ees 測定値と同数のEeg', Ees'を分析のために造 成する). 天空タイブとの相関が最も高くなるものを明らかにするた めにこの值の標準偏差を平均化時間ごとに求める.標準偏差が大き いほど, ある天空タイプに対応する日射量の值に散らばりがあり, 天空タイプ (Gradation, Indicatrixの各グループ) と日射量との関係 が小さい. 以下に，標淮偏差の算出方法を示す.

標準偏差の算出に際し, まず各平均化時間について, Gradation， Indicatrixの各グルーブの太陽高度幅 $5^{\circ}$ ごとにEeg', Ees'の平均值 $\overline{E e g}_{g n, m, \bar{t}, T}, \overline{E e s}_{i n, m, \bar{t}, T}$ を求める.

$$
\overline{E e g}=\sum_{i=1}^{N} E^{\prime} g^{\prime} / N
$$

※Ees'の場合も同様に算出する.

(以下 $(7) \sim(10),(17)$ 式についてもEeg'の場合の夕示す。） ここで

Eeg': 各平均化時間で平均した水平面全天日射量 $\left[\mathrm{W} / \mathrm{m}^{2}\right]$ Ees， :各平均化時間で平均した法線面直達日射量 $\left[\mathrm{W} / \mathrm{m}^{2}\right]$
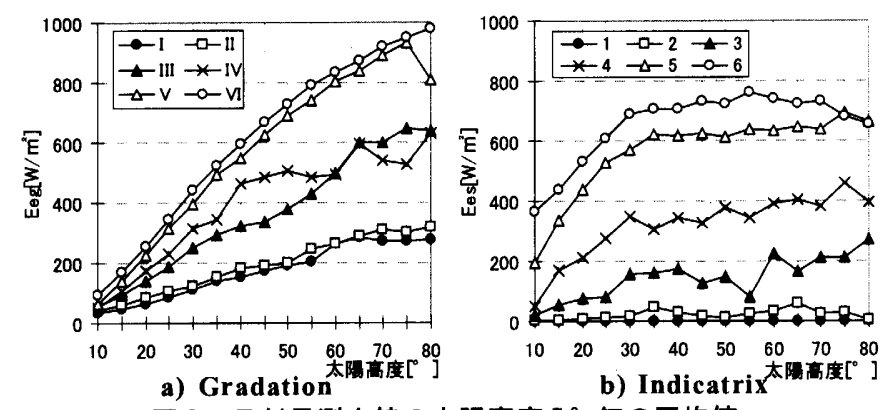

図 2 日射量測定值の太陽高度 $5^{\circ}$ 毎の平均值

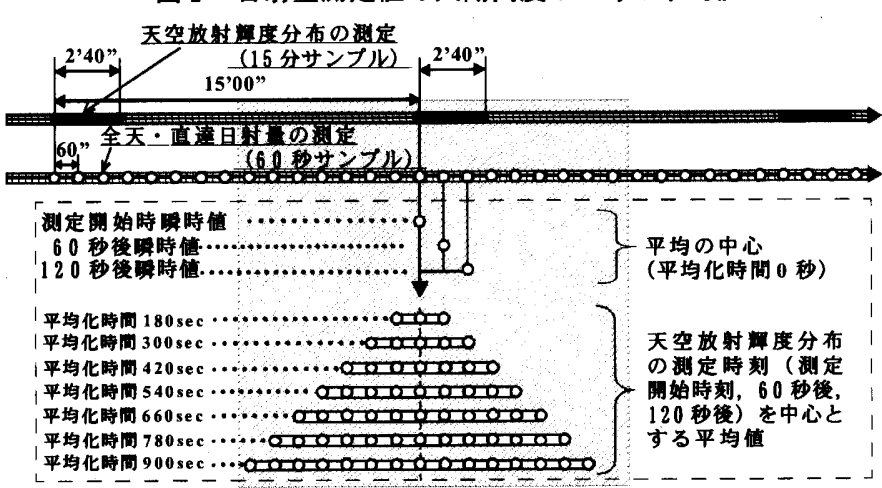

図 3 近似タイプを決定した RMSE の分布

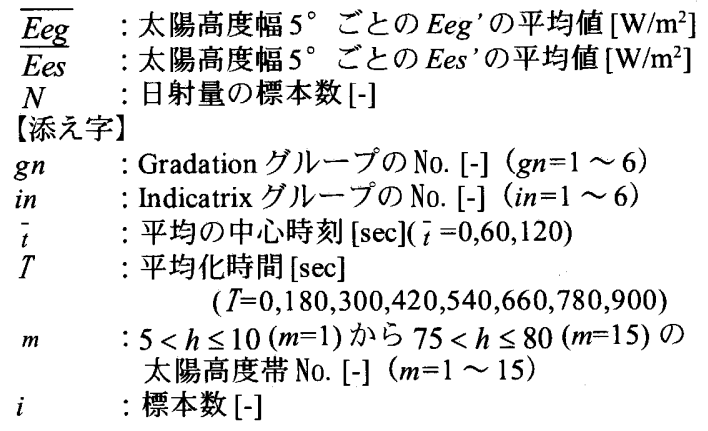

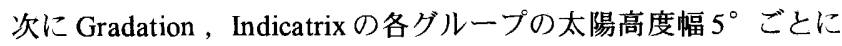
$E e g^{\prime}, E e s$ 'の標準偏差 $S D g_{g n, m, \bar{t}, T}, S D i_{i n, m, \bar{t}, T}$ を求める.

$$
S D g=\sqrt{\frac{\sum_{i=1}^{N}\left(E e g^{\prime}-\overline{E e g}\right)^{2}}{N-1}}
$$

求めた標準偏差 $S D g_{g n, m, \bar{t}, T}, S D i_{i n, m, \bar{t}, T}$ には, Gradation, Indicatrix の各グループごとに, Eeg', Ees'の平均値, 天空タイプの 出現頻度に違いがあるため, 太陽高度幅 $5^{\circ}$ ごとに, Eeg', Ees'の平 均値, Gradation, Indicatrix 各グループの出現頻度で重み付けを行 い, これを重み付け標準偏差 $S D g^{\prime}{ }_{g n, \bar{t}, T}, S D i^{\prime}{ }_{i n, \bar{t}, T}$ とする.

$$
S D g^{\prime}=\sum_{m=1}^{15}\left(S D g \times \frac{1}{\overline{E e g}} \times \frac{N}{\sum_{m=1}^{15} N}\right)
$$

求めた重夕付け標準偏差 $S D g_{g n, \bar{t}, T}^{\prime}, S D i^{\prime}{ }_{i n, \bar{i}, T}$ の比較には, 
$\bar{t}=0[\mathrm{sec}], \quad \boldsymbol{T}=0[\mathrm{sec}]$ （測定開始時刻の瞬時値）の重夕付け標準偏差 $S D g^{\prime}{ }_{g n, 0,0}, S D i^{\prime}{ }_{i n, 0,0}$ で基準化した基準化標準偏差 $\widehat{S D g}_{g n, \bar{t}, T}$ ， $\widetilde{S D i}_{i n, i, T}$ を用いる.

$$
\widetilde{S D g}_{g n, \bar{t}, T}=\frac{S D g^{\prime}{ }_{g n, \bar{t}, T}}{S D g_{g n, 0,0}^{\prime}}
$$

図 4，5にそれぞれ Gradation, Indicatrix 各グループのEeg', Ees' の基準化標準偏差 $\widetilde{S D g}_{g n, \bar{t}, T}[-], \widetilde{S D i}_{i n, \bar{t}, T}$ [-] 示す. $\widetilde{S D g}_{g n, \bar{t}, T}$ ， $\widetilde{S D i}_{i n, \bar{i}, T}$ が大きいほど,ある天空タイプに対応する日射量の值にち らばりがあり，天空タイプ (Gradation ,Indicatrixの各グループ）と 日射量の值の関係が小さくなることを意味する.

図 4a)によるとGradation グループ I, II では, 平均化時間 $\boldsymbol{T}$ の違 いによるEeg'の基準化標準偏差 $\widetilde{S D g}_{g n, \bar{t}, T}$ の変化はほとんど見られ ないが, グループIIIでは, 平均の中心 $t$ が $0,60,120 \mathrm{sec}$ そぞれ において, 平均化時間Tが長くなるにつれ $\widetilde{S D g}_{3, \bar{t}, T}$ が小さくなって いる。グループV,VIでは, $\bar{t}=0,60,120[\mathrm{sec}]$ それぞれに対し $T=0[\mathrm{sec}]$ で $\widetilde{S D g}_{g n, \bar{t}, T}$ が一番大きく, $\boldsymbol{T}=540 \sim 780[\mathrm{sec}]$ で最小となる.グルー

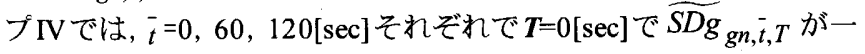
番大きいのはグループV, VIと同様であるが, $\boldsymbol{T}$ が長くなるにつれ $\widetilde{S D g}_{4, \bar{t}, T}$ は小さくなり, $\boldsymbol{T}=420[\mathrm{sec}]$ 場合に最小となる (図4b))。 この $\widehat{S D g}_{4, \bar{t}, T}$ の減少は他の Gradation グループと比べて大きく, $T=900[\mathrm{sec}]$ の場合に $\widetilde{S D g}_{4, \bar{t}, T}$ はおよそ0.8となる.

図 5a)の Indicatrix グループ 1，2，3の場合, グルーブ2，3では Tが長くなるに従ってEes'の基準化標準偏差 $\widetilde{S D i} i_{i n, \bar{t}, T}$ は小さくなる 傾向が見られるが, グループ1では $\boldsymbol{T}$ が長くなるに従って $\widetilde{S D i} i_{1, i}, T$ が增加する傾向があり，1.4を超えるものも見られる. Indicatrixグ ループ4〜6では (図 5b) ), グループ4では $\boldsymbol{T}$ が長くなるに従って Ees'の基準化標準偏差 $\widetilde{S D i}, \bar{i}, T$ は小さくなる傾向があるが, グルー プ 5,6では，逆にTが長くなるに従って $\widetilde{S D i} i_{i n, \bar{t}, T}$ が増加する傾向 が見られる。

次に, グルーブごとに求めた $\widehat{S D g}_{g n, \bar{t}, T}, \widetilde{S D i_{1}, \bar{t}, T}$ を Gradation, Indicatrix それぞれで平均し, Eeg', Ees'の基準化標準偏差 $\overline{S D g}_{t, T}^{-}$, $\overline{S D i} \bar{t}, T$ を求める.

$$
\overline{S D g}_{\bar{t}, T}=\sum_{g n=1}^{6} \widetilde{S D g}_{g n, \bar{t}, T} / 6
$$

さらに，日射量の平均化時間をGradation, Indicatrixで統一する ため, $\overline{S D g}_{\bar{t}, T}^{-}$と $\overline{S D i}_{i, T}^{-}$との平均し, 基準化標準偏差 $\overline{S D g i}_{t, T}^{-}$を求 める.

$$
\overline{\operatorname{SDgi}}_{t, T}^{-}=\left(\overline{S D g_{t, T}^{-}}+\overline{S D i_{t, T}^{-}}\right) / 2
$$

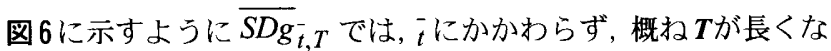
るに従い, $\overline{S D g}_{\bar{t}, T}^{-}$の值が小さくなる傾向が見られる.一方, $\overline{S D i} \bar{i}_{i}, T$ は，T=300〜 540[sec]までは, $T$ が長くなるに従い減少するが, さ らにTが長くなると増加に転じる傾向が見られる.

$\overline{S D g}_{t, T}^{-}, \overline{S D i}_{i, T}$ の平均である $\overline{S D g i}_{t, T}^{-}$の変化を見ると, $\boldsymbol{T}=300$
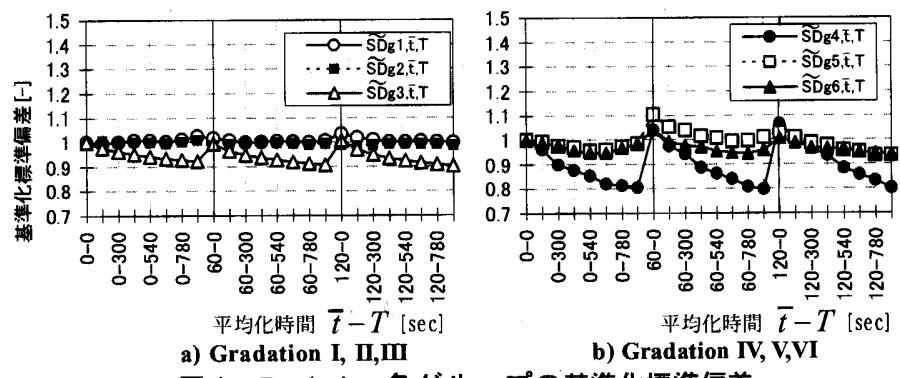

図 4 Gradation 各グループの基準化標準偏差
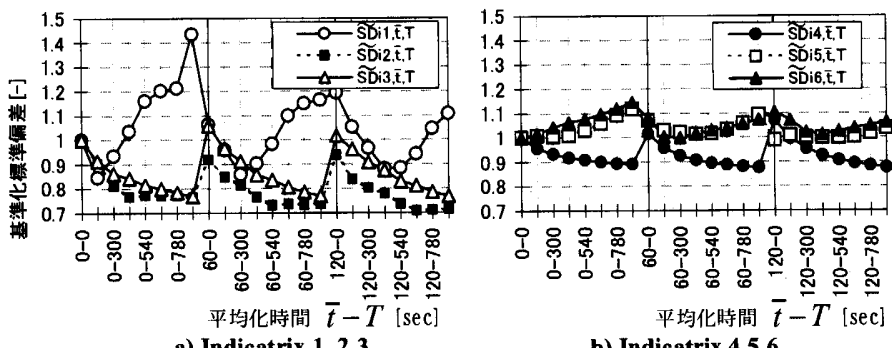

a) Indicatrix 1, 2,3

b) Indicatrix $4,5,6$

図 5 Indicatrix 各グループの基準化標準偏差

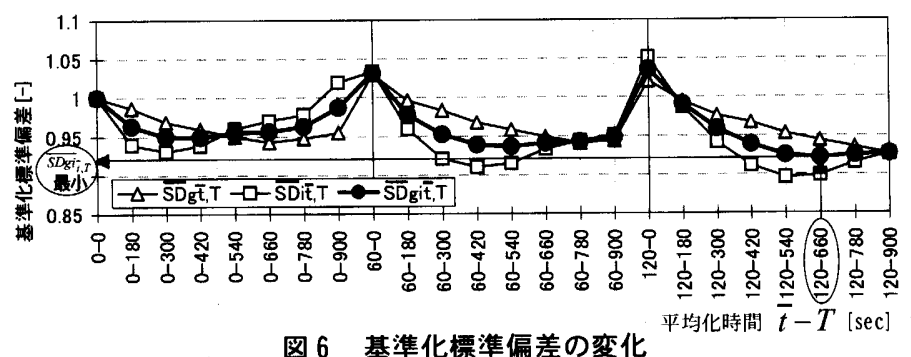

〜 540[sec]では, $\boldsymbol{T}$ が長くなるに従い減少するが, さらに $\boldsymbol{T}$ が長く なってもあまり変動は見られなくなる. $\overline{S D g i}{ }_{t, T}$ が最小となるのは, $\bar{t}=120[\mathrm{sec}], T=660[\mathrm{sec}]$ の場合である. 以上より, 本研究では, ス カイスキャナ測定開始後 $120 \mathrm{sec}$ を中とした前後 $300 \mathrm{sec}$ $(\boldsymbol{T}=660[\mathrm{sec}])$ の日射量を平均した值と天空タイプの関係を分析する こととする.

\section{4. 天空タイプ推定手法}

\section{1 近似タイプ決定の RMSE}

既報 ${ }^{6}$ では, 測定された天空放射輝度分布に一番近い天空タイプ

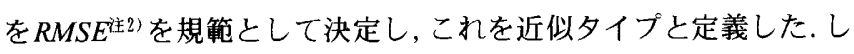
かしRMSEが小さくその天空タイプに類似度の高い天空状態もあれ ば, RMSEが大きく類似度が低いものもある. 図7に各近似タイプ の RMSEの累積度数分布を示す，例えば，累積度数 $80 \%$ に達する RMSEが 0.3 （天空タイブ3）から，0.7（天空タイプ 15）まである. 前者は主に曇天の天空タイプ (天空タイプ 3,1 ), 後者は晴天の天 空タイブ(天空タイブ 15,14 ) である. 近似タイブを決定するRMSE

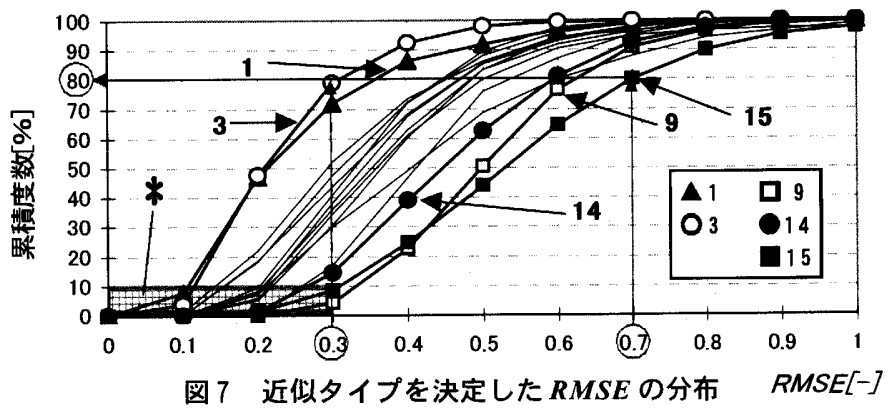


の闇値を小さくするほど標準一般天空の天空タイプにより近くなる が, その一方で度数が低下し, 十分な度数を確保できない天空夕イ プが出現し, 信頼度が落ちる.そこで本報では各天空タイプに対す る RMSEの累積度数上位 $10 \%$ にる観測值だけを用いて分析を行 弓. (図 7 領域*)

\section{2 境界曲線による天空タイプ推定}

図 2 に示すように, Gradation, Indicatrix ともに同じ高度に対し, グループの番号が大きくなるほど日射量の平均值は大きくなる. 各 天空タイプに対するRMSEの累積度数上位 $10 \%$ にるる類似度のより 高い近似タイプの Gradation, Indicatrix グループとEeg', Ees'を用 い, 図 2 の場合と同様に, 太陽高度幅 $5^{\circ}$ ごとに同一高度帯と定め て, Eeg', Ees'の平均值を求める (図 8), 一部の高度帯で平均值が 逆転するところも見られるが, 図2 と同様に各高度帯でグループ番 号が大きいものから順に並んでいる. そこで各グループ間に, 以下 の手順により境界を求めて, Gradation, Indicatrixの各グループを推 定することとする.

1) Gradation ,Indicatrix の各グループにおいて，近似タイプ決定の 際のRMSEが上位 $10 \%$ の時刻の近似タイプ, 日射量を分析に用い, その他の時刻のデー夕は除外する.

2）太陽高度帯 $5^{\circ}$ ごとに, 各グループのEeg', Ees' ${ }^{-}=120[\mathrm{sec}]$, $T=660[\mathrm{sec}]$ の平均值）の平均を求める.

3）太陽高度帯毎に, 隣あうグループの平均値の中間值 $\mathrm{Eeg}_{\text {med }}$, Ees ${ }_{\text {med }}$ を求める.

4) Gradation I, IIの太陽高度 $70^{\circ}$ の帯域のように平均値の逆転する

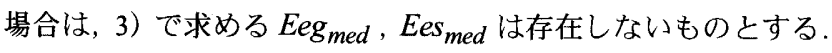

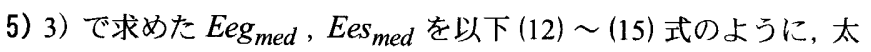
陽高度 $h$ の 3 次及び 2 次の関数で近似して, これをグループ推定の 為の境界注3) とする.これをそれぞれGradation境界曲線, Indicatrix 境界曲線と定義する.

\section{i) Gradation 境界曲線：}

$$
\begin{aligned}
& 3 \text { 次: } \mathrm{B}_{g, 3}=a_{g, 1} \cdot h^{3}+a_{g, 2} \cdot h^{2}+a_{g, 3} \cdot h+b_{g} \\
& 2 \text { 次: } \mathrm{B}_{g, 2}=a_{g, 1} \cdot h^{2}+a_{g, 2} \cdot h+b_{g}
\end{aligned}
$$

\section{ii） Indicatrix 境界曲線：}

$$
\begin{aligned}
3 \text { 次 : } & \mathrm{B}_{i, 3}=a_{i, 1} \cdot h^{3}+a_{i, 2} \cdot h^{2}+a_{i, 3} \cdot h+b_{i} \\
\text { 2 次 : } & \mathrm{B}_{i, 2}=a_{i, 1} \cdot h^{2}+a_{i, 2} \cdot h+b_{i} \\
\text { ここで, } & \\
& h: \text { 太陽高度 [0] } \\
& \alpha_{g, 1}, \alpha_{g, 2}, \alpha_{g, 3}, b_{g}: \text { Gradation 境界曲線の係数 [-] } \\
& \alpha_{i, 1}, \alpha_{i, 2}, \alpha_{i, 3}, b_{i}: \text { Indicatrix 境界曲線の係数 [-] }
\end{aligned}
$$

表 3 に Gradation 境界曲線の倸数を，表 4 に Indicatrix 境界曲線の 係数を，図 $9 に 3$ 次の Gradation,Indicatrix 境界曲線と各グループの 出現領域を示す。

\section{境界曲線の次数選択}

以上のような 3 次, 2 次の Gradation ,Indicatrix 境界曲線のモデルに ついて，それぞれ以下に示す AIC (Akaike’s Information Criterion) 10)を求め,これが小さくなる次数のものを,グルーブ推定の為の境 界曲線の最適モデルとして選択する。

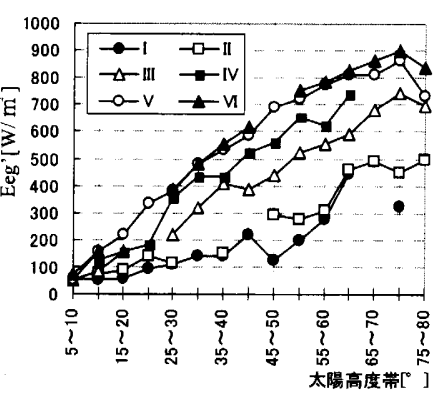

\begin{tabular}{|c|c|c|c|c|c|}
\hline \multirow{2}{*}{\multicolumn{2}{|c|}{ 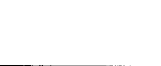 }} & \multicolumn{4}{|c|}{ INDICATRIX } \\
\hline & & $a_{i, 1}$ & $\overline{\overline{a_{i, 2}}}$ & $a_{i, 3}$ & $b_{i}$ \\
\hline \multirow{5}{*}{ 3次 } & $1-2$ & 0.0001 & -0.02 & 0.82 & -7.31 \\
\hline & $2-3$ & 0.0009 & -0.16 & 9.09 & -82.30 \\
\hline & 3-4 & 0.0019 & -0.32 & 17.05 & -79.19 \\
\hline & $4-5$ & 0.0030 & -0.54 & 29.20 & -67.36 \\
\hline & 5-6 & -0.0021 & 0.16 & 1.82 & 355.83 \\
\hline \multirow{5}{*}{ 2次 } & $1-2$ & -0.0009 & 0.24 & - & \\
\hline & $2-3$ & -0.0379 & 4.21 & - & -32.40 \\
\hline & 3-4 & -0.0583 & 6.84 & - & 23.61 \\
\hline & $4-5$ & -0.1287 & 13.30 & - & 92.61 \\
\hline & $5-6$ & -0.1729 & 18.03 & - & 116.71 \\
\hline
\end{tabular}

a) Gradation

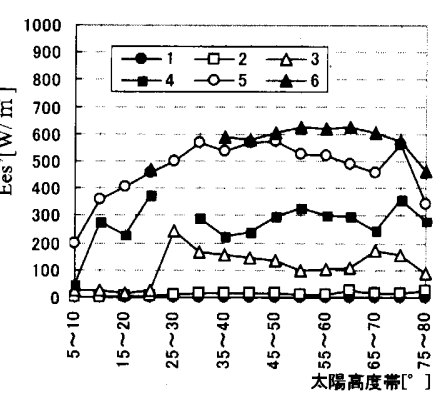

b) Incicatrix
図 8 日射量の高度別平均值 (15 タイプ)

表 3 境界曲線の係数（Gradation 15 タイプ）

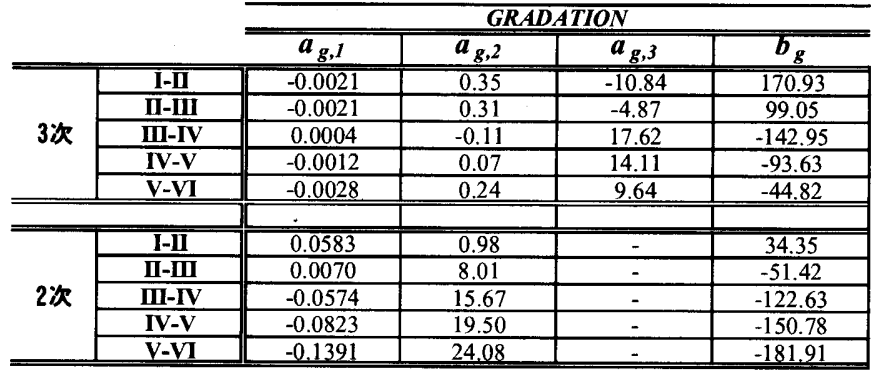

表 4 境界曲線の係数 (Indicatrix 15 タイプ)

\begin{tabular}{|c|c|c|c|c|c|c|c|}
\hline & & & & & \multirow{2}{*}{\multicolumn{3}{|c|}{ 3次 }} \\
\hline & \multicolumn{3}{|c|}{ 2次 } & & & \\
\hline & & & & & AIC & 残差半方相 & [T-多数 \\
\hline & I-II & 79.91 & 16211.50 & 10 & 81.08 & 14919.44 & 10 \\
\hline & II-III & 74.57 & 5607.53 & 11 & 72.06 & 3721.33 & 11 \\
\hline & III-IV & 59.79 & 2167.51 & 10 & 61.71 & 2150.69 & 10 \\
\hline & IV-V & 68.25 & & 11 & 69.72 & 3007.98 & 11 \\
\hline ङे & $V-V I$ & 86.70 & 9997.76 & 12 & 77.83 & 4040.32 & 12 \\
\hline \multicolumn{2}{|c|}{ average } & 3.84 & 7427.99 & & 72,0 & 550705 & \\
\hline
\end{tabular}

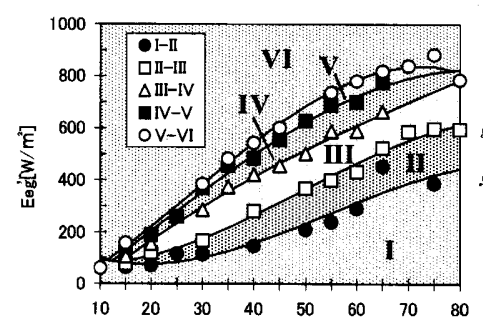

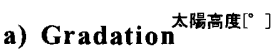

\begin{tabular}{|c|c|c|c|c|c|c|c|c|}
\hline & \multicolumn{3}{|c|}{ 2次 } & \multicolumn{3}{|c|}{ 3次 } & \multirow{2}{*}{$\begin{array}{l}\text { 㟟択すべ } \\
\text { きモデル } \\
\end{array}$} \\
\hline & & AIC & 残差平方和 & 宁一夕数 & AIC & 残差平方和 & データ数 & \\
\hline & 1-2 & 27.96 & 64.87 & 15 & 27.16 & 53.81 & 15 & \\
\hline & $2-3$ & 103.01 & 9654.69 & 15 & 103.75 & 77.57 & 15 & 2次 \\
\hline & 3-4 & 99.91 & 11466. & 14 & 97.72 & 8499.63 & 14 & 3次 \\
\hline & 4-5 & 113.87 & 31071. & 14 & 112.19 & 2388 & 14 & 3次 \\
\hline & $5-6$ & $\mathbf{7 2 . 4 3}$ & 7674.86 & 10 & 73.45 & 6958.05 & 10 & 2次 \\
\hline & 83.44 & 11986.54 & & 8285 & 9655.23 & & 3决 \\
\hline
\end{tabular}

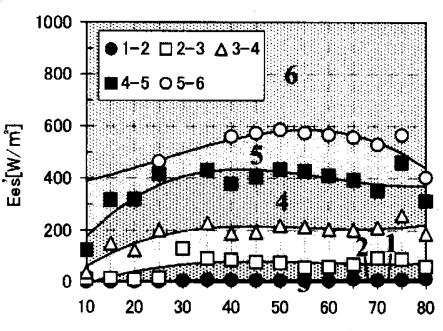

b) Indicatrix 太陽高度 $\left[^{\circ}\right.$
図 9 境界曲線と各グループの出現領域（3 次）

表 5 Gradation 境界曲線の AIC, 残差平方和, デー夕数

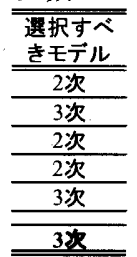

表 6 Indicatrix 境界曲線の AIC, 残差平方和, デー夕数 


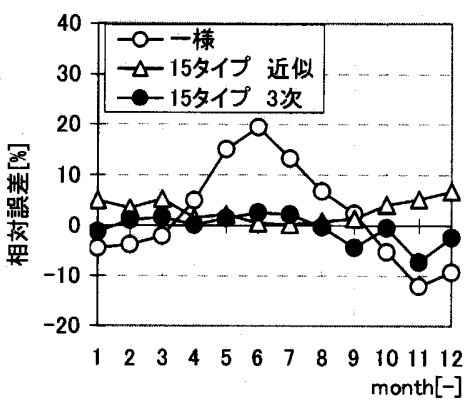

a) South

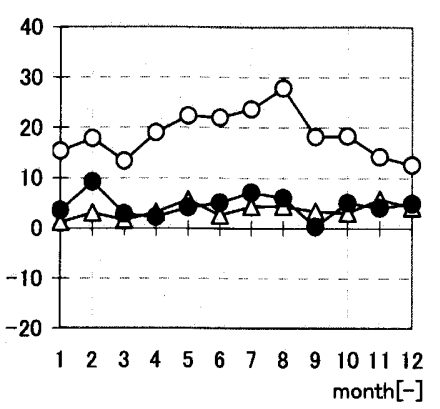

b) West

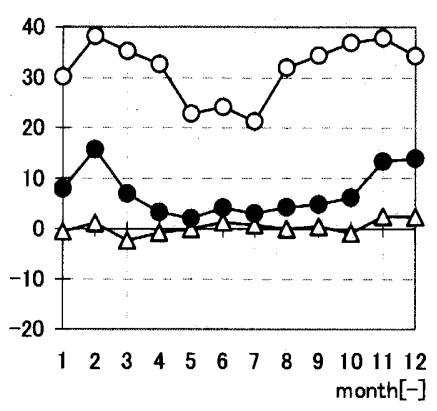

c) North

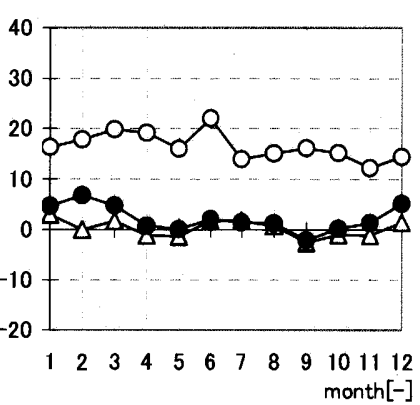

d) East

図 10 鉛直面日射量相対諮差の月平均

$$
\begin{gathered}
A I C=N \log (Q / N)+2(p+1) \\
Q=\sum\left(E e g_{m e d}-B_{g, p}\right)^{2} \\
\text { ここで, } \\
Q \quad: \text { 残差平方和 } \\
E e g_{m e d}: \text { 太陽高度帯毎の中間値 (日射量) } \\
B_{g, p} \quad: \text { モデルによる各太陽高度帯の日射量 } \\
p \quad: \text { モデル次数 } \\
N \quad: \text { デー夕数 }
\end{gathered}
$$

表 5，6にGradation, Indicatrix境界曲線のAIC, 残差平方和, デー 夕数を示す. AICについてはGradation, Indicatrixの各5 本の境界曲 線についてそれぞれ求める。

AICは, 2次あるいは3次のものの一方がすべての境界曲線につ いて小さくならない。このため, Gradation, Indicatrix境界曲線につ いて, 2 次, 3 次の AICの平均を求める.これによれば Gradation, Indicatrix 境界曲線ともに, 3 次のモデルのAICが小さくなる. 以上 より境界曲線の次数は3次とする.

\section{3 鉛直面日射量注4)}

境界曲線により推定したGradation , Indicatrixの各関数のグルー プから推定した天空タイプより,東西南北四方位の鉛直面日射量を 求め, スカイスキャナにより測定された天空放射輝度分布によって 求めた鈶直面日射量 $I_{m, s h}\left[\mathrm{~W} / \mathrm{m}^{2}\right]$ に対する相対誤差で比較すること で,この推定手法の妥当性を検証する.

$I_{m, s h}$ に対する $I_{i-15, s h}, I_{u, s h}$, 既報で求めた近似タイプの場合の 鉛直面日射量 $I_{c, s h}$ それぞれの相対誤差注 5) $I_{i-15, r e}, I_{u, r e}, I_{c, r e}$ の各 月平均值を求め, 比較を行う.

図10から,全方位について一様天空の場合と比べ精度良く鉛直面 日射量を求めることができていることがわかる.

南面では， $I_{i-15, r e}$ は, 一年を通し概ね $\pm 5 \%$ 未満で, 精度は良い また，一般に熱環境シミュレーションの際に仮定される一様天空の $I_{u, r e}$ は冬季に $-12.1 \%$, 夏季に+19.5\%となり誤差が大きい.

西面では， $I_{i-15, r e}$ は2月に $9.0 \%$ 超えるが，他の月では概ね $+5 \%$ 未満で精度は良い. また年間の変動は最大で $8 \%$ 程度である. 一方, $I_{u, r e}$ は一年を通して $10.0 \%$ を超え, 最小でも $12.5 \%$ (12月), 最大で $27.9 \%$ (8月)である.

北面では， $I_{i-15, r e}$ は2月，11月，12月に $10.0 \%$ 超えるなど冬季 にやや大きいが,その他の月では概ね+5\%程度であり,精度よく鉛 直面日射量を求められている.また $I_{u, r e}$ は一年を通して $20.0 \%$ を超 え, 最小でも $21.3 \%$ (7月), 最大で $38.2 \%$ (2月) となり， $I_{i-15, r e}$
と比べ格段に大きい.

東面では， $I_{i-15, r e}$ は，冬季に (2月 6.8\%) やや大きくなるもの の, 一年を通し概ね $\pm 5 \%$ 以下と小さい. $I_{c, r e}$ と比べても冬季にや や大きくなる以外はほぼ同程度の值を示しており,精度よく鉛直面 日射量を求められている.これに比べ $I_{u, r e}$ は一年を通し概ね $+15 \%$ 以上と大きい.

以上のように, 相対誤差 $I_{i-15, r e}$ は北面, 西面で冬季にやや大きい が，概ね $\pm 5 \%$ 未満であり, 精度はよい. 既報で求めた $I_{c, r e}$ と比較 しても抙色の無いモデルである.一方, 現在一般的に用いられてい る一様天空の場合と比べると相対誤差は十分小さい.

\section{5. 天空タイプ5タイプの推定}

\section{1 境界曲線による天空タイプ推定}

既報)で示したように, 近似する天空タイプを15から出現頻度の 低い順に減少させてゆくと, 鉛直面日射量のRMSEは天空タイプの 数が5以上では大きな変化は無いが, 4以下になると南, 西面ではそ れまでより約 $10\left[\mathrm{~W} / \mathrm{m}^{2}\right]$ 大きくなり, 東面ではRMSEの季節差が 2.3 倍になるなど急に誤差が大きくなる傾向が見られた.CIE標準一般 天空の天空タイプは15タイプに規定されているが, 天空タイプの数 を15から隇らすことができれば,より少ない天空タイプを推定すれ ばよいことになり，推定が容易になると考える，そこで本報では、既 報に基づき天空タイプを5つに集約した場合に天空タイプ推定手法 を適用する. 集約した5つの天空タイプは $1,8,13,14,15$ あるあ. 天 空タイプ 1 の輝度階調関数, 散乱関数グループの組み合わせはIと1 であり, 天空タイプ $8,13,14,15$ の組み合わせはそれぞれ III と $4, \mathrm{~V}$ と 5 , VI と 5, VI と6である. これより, 集約した 5 つの天空タイブ を推定するには, 輝度階調関数 (Gradation) グループではI, III, V, VI を, 散乱関数 (Indicatrix) グループでは 1，4，5，6をそれぞれ 水平面全天日射量 $E e g$ ', 法線面直達日射量Ees'から推定すればよい ことになる.このためGradationグループでは I-III, III-V, Indicatrix

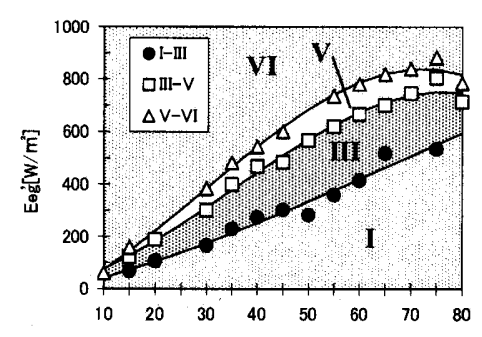

a) Gradation 太降高度 $\left[^{\circ}\right]$

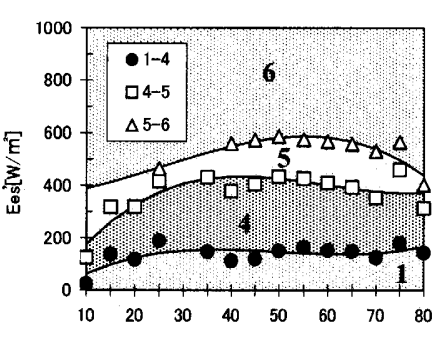

b) Indicatrix 太陽高度 $\left[{ }^{\circ}\right]$ 


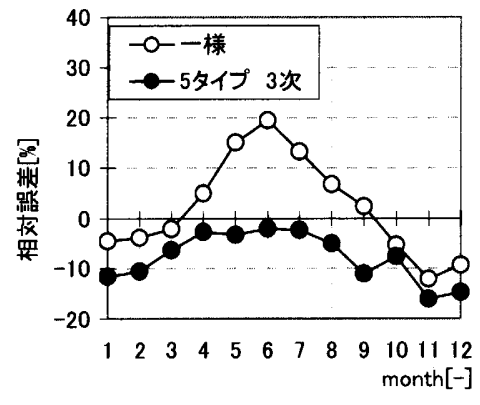

a) South

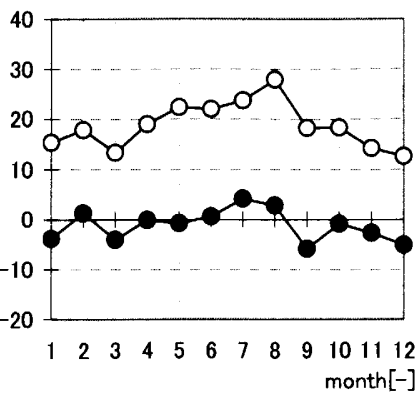

b) West

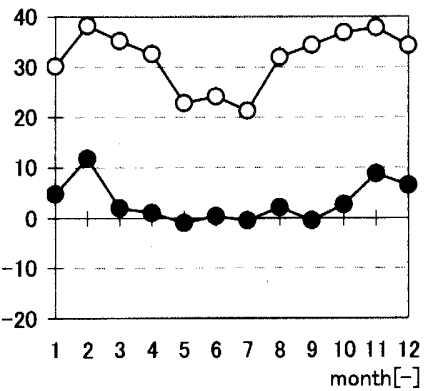

c) North

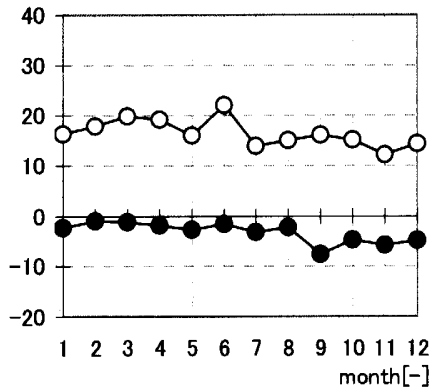

d) East

図 12 鉛直面日射量相対誤差の月平均

グループでは1-4の境界曲線を新たに求める.

図11に境界曲線と各グループの出現領域を示す.この時の境界曲 線は以下の様になる. 境界曲線の係数の表中網掛け太文字のものが 新たに求め Gradation, Indicatrix 境界曲線の係数である.

i) Gradation 境界曲線 :

$$
\begin{aligned}
& \text { 3 次: } \mathrm{B}_{g, 3}=a_{g, 1} \cdot h^{3}+a_{g, 2} \cdot h^{2}+a_{g, 3} \cdot h+b_{g} \\
& \text { ここで, } \\
& \begin{array}{|l|l|l|l}
a_{g, 1} & a_{g, 2} & a_{g, 3} & b_{g} \\
\hline
\end{array} \\
& \begin{array}{l|l|l|l|l}
\hline \text { I-Ti } & -0.0003 & 0.06 & 4.62 & -9.51 \\
\hline
\end{array} \\
& \begin{array}{l|l|l|l|l}
\hline \text { III-V } & -0.0025 & 0.26 & 4.68 & 6.88 \\
\hline
\end{array} \\
& \begin{array}{l|l|l|l|l}
\hline \text { V-VI } & -0.0028 & 0.24 & 9.64 & -44.82
\end{array}
\end{aligned}
$$

ii) Indicatrix 境界曲線 :

$$
\begin{aligned}
& 3 \text { 次: } \mathrm{B}_{i, 3}=a_{i, 1} \cdot h^{3}+a_{i, 2} \cdot h^{2}+a_{i, 3} \cdot h+b_{i} \\
& \text { ここで, } \\
& \begin{array}{c||c|c|c|c} 
& a_{i, 1} & a_{i, 2} & a_{i, 3} & b_{i} \\
\hline \hline \mathbf{1 - 4} & \mathbf{0 . 0 0 1 9} & -0.29 & \mathbf{1 3 . 4 1} & -\mathbf{4 5 . 2 3} \\
\hline \mathbf{4 - 5} & 0.0030 & -0.54 & 29.20 & -67.36 \\
\hline \mathbf{5 - 6} & -0.0021 & 0.16 & 1.82 & 355.83
\end{array}
\end{aligned}
$$

\section{2 鉛直面日射量}

境界曲線により推定した天空タイプを用いて鉛直面日射量 $I_{i-5, s h}$ を求め, $I_{m, s h}$ に対する相対誤差 $I_{i-5, r e}$ の各月平均值を求め, 精度の 検証を行う. 図12に測定值より求めた鉛直面日射量 $I_{m, s h}$ に対する, 本手法で求めた鉛直面日射量 $I_{i-5, s h}$, 一様天空の鉣直面日射量 $I_{u, s h}$ の相対誤差 $I_{i-5, r e}, I_{u, r e}$ の各月平均値を示す.

南面では, $I_{i-5, r e}$ は 3 月から 8 月は-5\%以下であり, 精度よいが, 冬季には $I_{u, r e}$ と同程度となり, 11 月, 12 月には $15 \%$ 程度と精度が 悪くなる。

西面では, $I_{i-5, r e}$ は, 9月に-5.8\%となり他の月と比べやや大きく なるものの, それ以外の月は $5 \%$ 未満であり, 精度よく鈆直面日 射量を求められている.

北面では, $I_{i-5, r e}$ は, 2 月に $10.0 \%$ 超えるものの, その他の月で は精度よく,一年を通して $20.0 \%$ を超える $I_{u, r e}$ と比べても格段に小 さく, 大きな年間変動も見られない.

東面では, $I_{i-5, r e}$ は, 一年を通し $\pm 5 \%$ 以下と小さく, 精度よく鈶 直面日射量を求められている.

また,15タイプ, 5タイプの天空タイプを推定し鈶直面日射量を

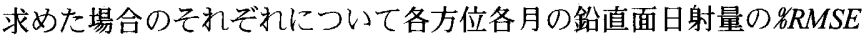

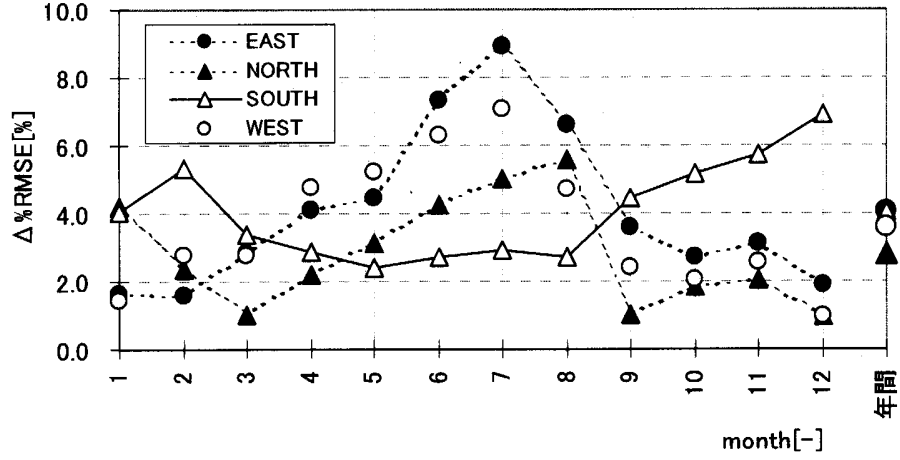

図 13 鉛直面日射量の\%RMSE の差

を求め, この差 $\triangle$ 政 $M S E$ より, 15 タイプの場合からの精度低下を 検証する。

$$
\begin{aligned}
& \% R M S E_{5}=100 \times \frac{\sqrt{\sum\left(I_{i-5, s h}-I_{m, s h}\right)^{2} / k}}{\sum I_{m, s h} / k} \\
& \% R M S E_{15}=100 \times \frac{\sqrt{\sum\left(I_{i-15, s h}-I_{m, s h}\right)^{2} / k}}{\sum I_{m, s h} / k} \\
& \Delta \% R M S E=\% R M S E_{5}-\% R M S E_{15} \\
& \text { ここで, }
\end{aligned}
$$

\section{$k:$ 各方位各月の鈶直面日射量計算值の個数 [-]}

図13に各方位各月の $\triangle{ }^{\prime} R M S E$ を示す. 15タイブの場合と比べ5タ イプの場合は年間で北面 $2.8 \%$ 南面 $4.1 \%$ 東面 $3.6 \%$ 西面 $4.1 \%$ の精度 低下が見られる. 季節では東面・西面夏季、南面冬季に $\triangle$ oRMSEが $5 \%$ を超えることもあるが, 最大でも $8.9 \%$ (東面 7月) であり, 著 しく大きくなることはないと判断した.

6. 結

散乱関数（Indicatrix function）のグループと法線面直達日射量 Ees', 輝度階調関数（Gradation function）のグルーブと水平面全天 日射量Eeg'の関係を分析し, Gradation,Indicatrixの各グループを推 定するための各グループの区分を表す境界曲線を求め,これより天 空タイブを推定する手法を開発した.

1) 推定した天空タイブを用いて求めた鈶直面日射量に対する相対 誤差を分析した. 本報で提案する天空タイプ推定手法を用いた場合 
の鉛直面日射量の相対誤差月平均 $I_{i-15, r e}$ は, 北面, 東面で冬季にや や大きくなる傾向が見られたものの, 概ね $\pm 5 \%$ 未満であり精度よ く鈶直面日射量が求められている.従来の一様天空の場合と比べて もその值は十分小さい. また既報で求めた近似タイプの相対誤差 $I_{c, r e}$ と比較しても著しく大きくなることはなかった.これより本研 究で提案する天空タイプ推定手法の妥当性を示すことができた

2) 天空タイプ推定手法を, 既報で集約した $1,8,13,14,15$ のつ天 空タイプの場合に適用して求めた $I_{i-5, r e}$ の相対誤差は南面, 北面の 冬季に土10.0\%を超える月も見られたが，15タイプ,5タイプ場合 のそれぞれについて各方位各月の鈶直面日射量の この差 $\triangle$ 政MSEより, 15タイプの場合からの精度低下を検証した ところ, 東面・西面夏季、南面冬季に $\triangle$ 解 $M S E$ は $5 \%$ を超えること もあるが，最大でも $8.9 \%$ (東面 7 月）であり，著しく大きくな ることはないと判断した.これより15の時と同様集約した天空タイ プの推定にも本報の天空タイプ推定手法を利用し, 精度よく鈶直面 日射量を求められることを示した。

\section{注}

注 1) 天空放射輝度・天空輝度分布測定値, 及び各種日射計測定値の補正

以下の補正を行った。

(1)水平面拡散日射量は, 遮蔽バンドの補正を1日単位で行う9。

(2)スカイスキャナの測定上限值(放射輝度 $300\left[\mathrm{~W} / \mathrm{m}^{2} \cdot \mathrm{sr}\right]$, 輝度 $55,000\left[\mathrm{~cd} / \mathrm{m}^{2}\right]$ ) を超える天空要素の放射輝度测定值は, 輝度測定値を用いた補正(参考文献6注 記 4 参照)。

(3)スカイスキャナ天空要素の第一高度帯 (高度角 $6^{\circ}$, 天空要素№. 1 N No. 30) の測 定值は, 周辺地物の影響を受けているので, 近似夕イプの第二高度帯の値を用いた 補正を行う(参考文献 6 注記 6 参照)。

注 2) 近似タイプの RMSE

近似タイプのRMSEは既報6の（7）式を用いて計算した

注 3) Gradation, Indicatrix グループの判定

3次の境界曲線を求めた時, 低高度带 $\left(10^{\circ}\right)$ で曲線が交差するものが見られた が,交差領城のグルーブ判定はグループ番号の小さいものを優先した。

注4) 鉣直面日射量

スカイスキャナによる天空放射輝度分布測定值、一様天空、天空タイプを用いた 鈆直面日射量の算出方法については、参考文献 6 の 4 章 4 節を参照

注5) スカイスキャナ測定值から求めた鉣淔佰目射量に対する相対誤差は以下の式を 用いて算出した。

$$
I_{c, r e}=\frac{\left(I_{c, s h}-I_{\mathrm{m}, s h}\right)}{I_{\mathrm{m}, s h}} \times 100
$$

$I_{u, s h}, I_{i-15, s h}, I_{i-5, s h}$ の相対誤差については $I_{c, s h}$ に代えて, $I_{u, s h}, I_{i-15 . s h}$,

$I_{i-5, s h}$ を用いる。相対誤差は $I_{u, r e}, I_{i-15 . r e}, I_{i-5 . r e}$ となる。

\section{【記号表】}

$\chi$ : 太陽と天球上任意点の角距離 $[\mathrm{rad}]$

$Z$ : 天球上任意点の天頂角 $[\mathrm{rad}]$

$Z_{s}$ : 天頂からの太陽高度 $[\mathrm{rad}]$

$a, b \quad$ : 辉度階調関数のバラメータ [-]

$c, d, e \quad$ : 散乱関数のバラメータ [-]

$\alpha \quad$ : 天球上任意点の方位角 $[\mathrm{rad}]$

$\alpha_{s} \quad$ : 太陽方位角 [rad]

$h \quad$ : 太隄高度 [ $\left.{ }^{\circ}\right]$

$\alpha_{g, 1}, \alpha_{g, 2}, \alpha_{g, 3}, b_{g}:$ Gradation 境界曲線の係数 [-]

$\alpha_{i, 1}, \alpha_{i, 2}, \alpha_{i, 3}, b_{i} \quad$ : Indicatrix 境界曲線の係数 [-]

$I_{m, s h}$ : スカイスキャナ測定值から求めた鈶㨁面日射量 $\left[\mathrm{W} / \mathrm{m}^{2}\right]$

$I_{c, s h}$ : 決定手法による天空タイプによる鈶直面日射量 $\left[\mathrm{W} / \mathrm{m}^{2}\right]$

$I_{u, s h} \quad:$ 様天空による鈆直面日射量 $\left[\mathrm{W} / \mathrm{m}^{2}\right]$

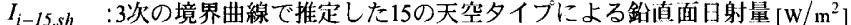

$I_{i-5 . s h}: 3$ 次の境界曲線で推定した5の天空タイプによる鈆直面日射量 $\left[\mathrm{W} / \mathrm{m}^{2}\right]$

$I_{c, r e} \quad: I_{c, s h}$ の $I_{m, s h}$ に対する相対䛣差 [\%]

$I_{u, r e} \quad: I_{u, s h}$ の $I_{m, s h}$ に対する相対詋差 [\%]

$I_{i-15, r e}: I_{i-15, s h}$ の $I_{m, s h}$ に対する相対誤差 [\%]

$I_{i-5, r e}: I_{i-5, s h}$ の $I_{m, s h}$ に対する相対誤差 $[$ \% $]$

Eeg : 水平面全天日射量测定值 $\left[\mathrm{W} / \mathrm{m}^{2}\right]$

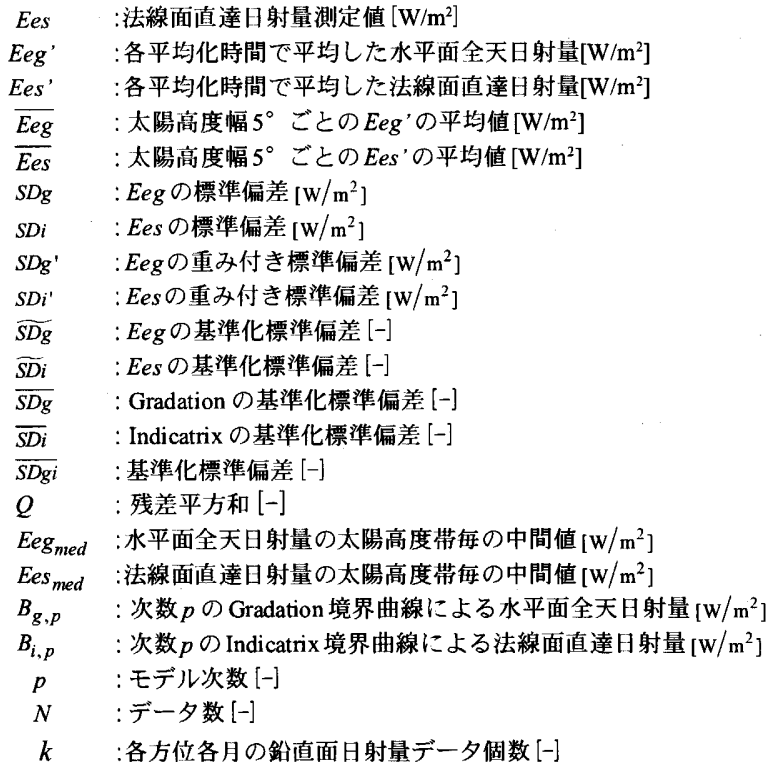

\section{【添え字】}

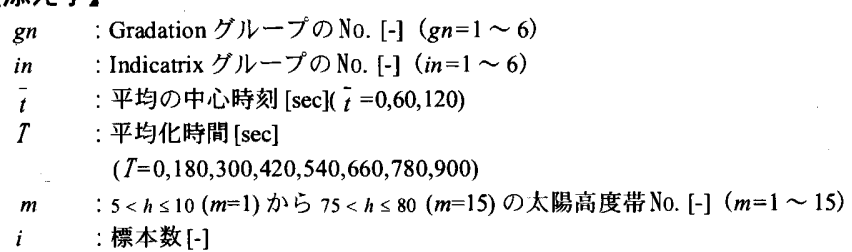

\section{参考文献}

1) Perez, R., Seals, R., and Michalsky, j.: All-Weather Model for Sky Luminance Dis-tribution - Preliminary Configuration and Validation, Solar Energy, 50 (3), pp. 235-245, 1993

2) Perez, R., Ineichen, P., Seals, R., Michalsky, j., and Stewart, R. : Modeling Day Light Availability and Irradiance Components from Dirct and Global Irradiancen, Solar Energy, 44(5), pp. 271289, 1990

3）井川憲男, 中村洋, 松澤朋子, 古賀靖子, 穴井謙 : すべての天空状態の天空放 射輝度分布を示す数式と鈶直面日射量の推定, 天空放射輝度分布のモデル化に 関する研究 (その 2)，日本建築学会計画系論文集, 第557号, pp. 17-24, 2002. 7

4) Kittler, R., Perez, R. and Darula, S. : A Set of Stndard Skies Characterising Daylight Conditions for Computer and Energy Conscious Design, Final Report of U.S. -Slovak Grant Project US-SK 92052,1998

5) CIE Standard: Spitial Distribution of Daylight-CIE Stndard General Sky

CIE S $011.1 / \mathrm{E}, 2003$.

6) 細淵勇人, 吉田治典, 上谷芳昭:天空放射辉度分布へのCIE標準一般天空の 流用と天空夕イプの集約，口本建築学会環境系論文集，第583号，pp. 2936.2004 .9

7) CIE TC 3-07: Guide to Recommended Practice of Daylight Measurement, CIE, Technical Report108-1994

8）柴田要，中村洋，大鶴徹，古賀靖子，田中信之:CIEの昼光測定のガイドによ る昼光測定データの品質管理の試み, 日本建築学会九州支部研究報告。 第 32 号, pp. 37-40, 1991. 3

9) 日本建築学会 : 建築環境「学実験用教材 I，環境测定演習編，1982

10）情報量基準による統計解析入門，鈴木義一郎，講談社，1995 (2006年 3 月 10 日原稿受理， 2006 年 8 月 9 日採用決定 